Bull. Mater. Sci., Vol. 13, No. 3, June 1990, pp. 173-178. (C) Printed in India.

\title{
Preparation and characterization of silicon nitride-silicon carbide composites
}

\author{
N KISHAN REDDY* and J MUKERJI $\dagger$ \\ Indian Institute of Chemical Technology, Hyderabad 500007 , India \\ tCentral Glass and Ceramic Research Institute, Calcutta 700 032, India \\ MS received 21 August 1989; revised 15 December 1989
}

\begin{abstract}
Silicon nitride-silicon carbide $\left(\mathrm{Si}_{3} \mathrm{~N}_{4}-\mathrm{SiC}\right)$ composites were prepared by varying the percentage of silicon nitride at temperatures of 1350 to $1450^{\circ} \mathrm{C}$. The mechanical and thermal properties of these composites were determined. The modulus of rupture of the composites increases with increase of temperature whereas the thermat expansion decreases. Composites with $10 \%$ and $50 \% \mathrm{Si}_{3} \mathrm{~N}_{4}$ have modulus of rupture of 49 and $86 \mathrm{MPa}$ at $1400^{\circ} \mathrm{C}$ and thermal expansion coefficients $\left(25^{\circ}-1000^{\circ} \mathrm{C}\right)$ of $4.4 \times 10^{-6}$ and $3.2 \times 10^{-6 \circ} \mathrm{C}^{-1}$ respectively.
\end{abstract}

Keywords. Silicon nitride-silicon carbide composites; modulus of rupture; coefficient of thermal expansion.

\section{Introduction}

Silicon carbide and silicon nitride are prime candidates for ceramic components in gas turbine engines, heat exchangers, fusion reactors and wear-resistant seals (North and Kilchrist 1981; Trantina 1979; Uchida et al 1985; Govila et al 1985; Jacobsen and Smialek 1985). The properties of these materials which make them unique for these kinds of applications are their high mechanical strength, good oxidation resistance, high thermal conductivity and low thermal expansion. Materials that offer much promise for automobile, jet and rocket engines are composites based on silicon carbide, silicon nitride and transformation-toughened zirconia (Buljan et al 1987; Mecholsky 1989; Tennery 1989). Silicon nitride-silicon carbide $\left(\mathrm{Si}_{3} \mathrm{~N}_{4}-\mathrm{SiC}\right)$ composites have been prepared by firing green shapes $(15.2 \times 1.9 \times 1.3 \mathrm{~cm})$ dimensions of silicon carbide and silicon in a nitrogen atmosphere (Krasotkina and Voronin 1970; Pick 1979; Mukerji and Reddy 1980; Reddy and Mukerji 1988). The modulus of rupture (MOR) of these composites has been compared with that of other conventional silicon carbide refractories (Washburn and Love 1962). This paper deals with the modulus of rupture and thermal expansion of silicon nitridesilicon carbide composites having 10 to $50 \% \mathrm{Si}_{3} \mathrm{~N}_{4}$.

\section{Experimental}

Commercial silicon carbide and silicon were used for the preparation of batches. Several batches were made with silicon carbide of $100,200,600$ mesh sizes and silicon of 200 mesh size. One percent of polyvinyl alcohol was added to the thoroughly mixed batch as a binder. Rectangular samples $(15.2 \times 1.9 \times 1.3 \mathrm{~cm})$ were made by pressing at 7 tons/in ${ }^{2}$. Green shapes were dried in an oven at $200^{\circ} \mathrm{C}$ for

*For correspondence 
$2 \mathrm{~h}$. The percentage of silicon in the batch was varied in order to get $10,20,30,40$ and $50 \%$ silicon nitride in composites after nitridation. A crucilite element-heated impervious sintered-alumina tube furnace capable of working under high vacuum or controlled atmospheres was used for the experiment. The green shapes were fired in a nitrogen atmosphere. The nitriding temperature was varied from 1350 to $1450^{\circ} \mathrm{C}$.

Densities and porosities of the samples were determined by the immersion method. The room temperature MOR was determined using an Instron Universal Testing Machine model 1195. Specimens of rectangular cross-section $(15.2 \times 1.9 \times$ $1.3 \mathrm{~cm}$ ) were used for the tests. The sample was tested by three-point bending. The load was applied at the centre of the specimen at a rate of $50 \mathrm{~kg} / \mathrm{min}$. The MOR was determined using the formula

$$
W=3 P L /\left(2 b d^{2}\right)
$$

where $W$ is the MOR, $P$ the total load at which the specimen failed, $L$ the distance between the supports, $b$ the width of the specimen and $d$ the depth of the specimen.

The hot MOR of samples was determined by using a furnace which can go up to a temperature of $1500^{\circ} \mathrm{C}$. The furnace was fitted with a load cell, a load indicator and a temperature indicator. The knife edges and thrust rods were made of zirconiamullite refractory. The test bars $(15.2 \times 1.9 \times 1.3 \mathrm{~cm})$ were introduced into the furnace and the temperature of the furnace was gradually increased to the desired

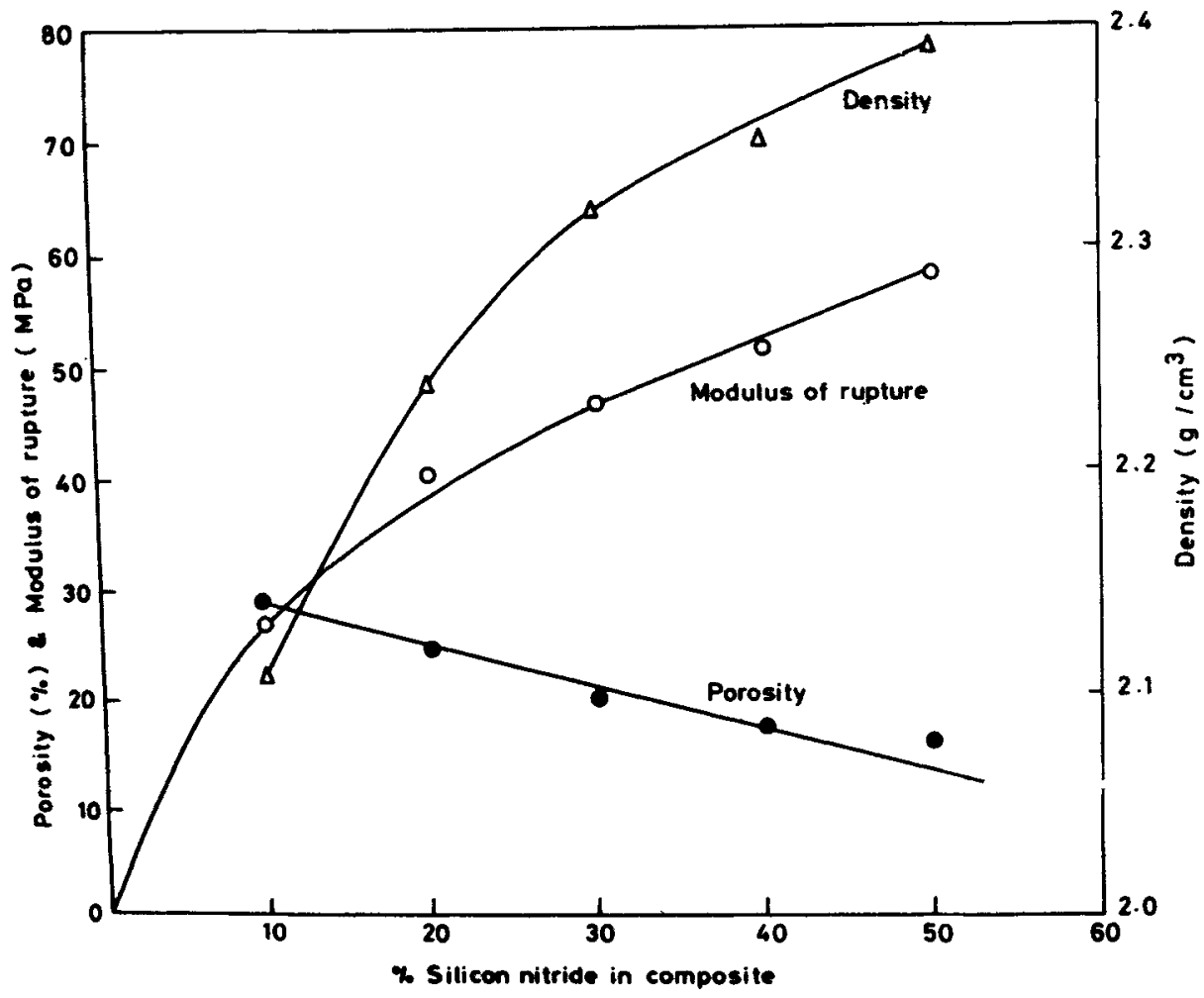

Figure 1. Variation of $\%$ silicon nitride in composite with density, porosity and room temperature modulus of rupture. 
temperature $\left(1250,1350\right.$ or $\left.1400^{\circ} \mathrm{C}\right)$. The test bar was pushed under the thrust rod. The load was applied exactly at the centre of the specimen and the value was noted from the load indicator. The hot MOR was calculated using the above formula.

\section{Results and discussions}

Variation of room temperature MOR with percent silicon nitride in the composite is given in figure 1. It is seen from the figure that the MOR increases rapidly from zero to $30 \% \mathrm{Si}_{3} \mathrm{~N}_{4}$ in the composite and thereafter increases linearly at a decreased rate up to $50 \% \mathrm{Si}_{3} \mathrm{~N}_{4}$ composition. Percent silicon nitride in the composite vs density and porosity are shown in figure 1 . As percent silicon nitride in the composite increases, density increases and porosity decreases (figure 1). From these results it may be noted that there is a direct relation of percent increase of silicon nitride in the composite with density and MOR. The room temperature MOR increases from $27 \mathrm{MPa}$ to $58 \mathrm{MPa}$ as $\mathrm{Si}_{3} \mathrm{~N}_{4}$ in the composite increases from 10 to $50 \%$. Hot MOR was determined at 1250,1350 and $1400^{\circ} \mathrm{C}$. The values are shown in figure 2. It is seen from the figure that. MOR of a composite increases with

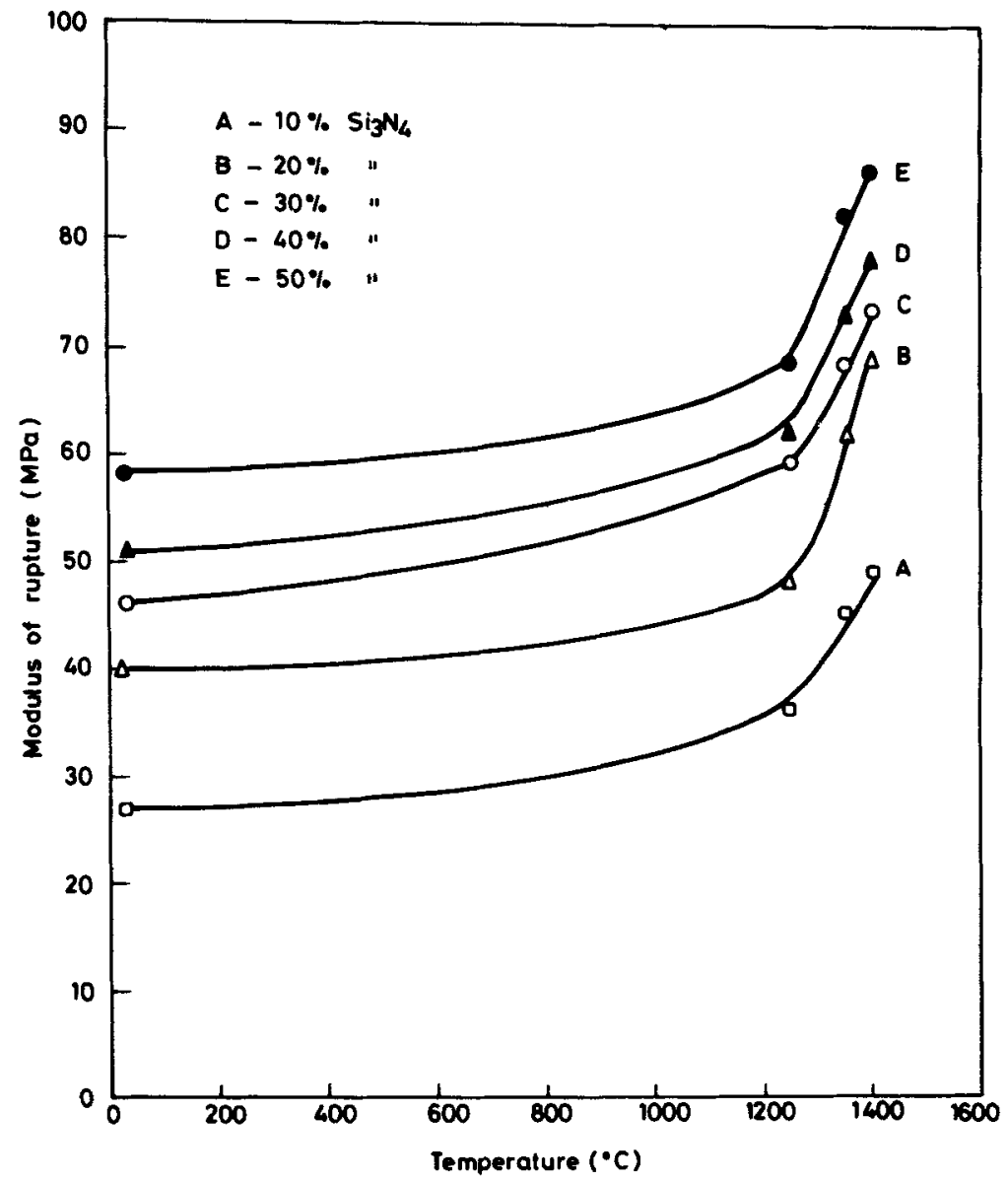

Figure 2. Hot modulus of rupture of $\mathrm{Si}_{3} \mathrm{~N}_{4}-\mathrm{SiC}$ composites. 
increase of temperature. Composites with 10 and $50 \% \mathrm{Si}_{3} \mathrm{~N}_{4}$ have room temperature MOR values of 27 and $58 \mathrm{MPa}$ whereas the values at $1400^{\circ} \mathrm{C}$ are 49 and $86 \mathrm{MPa}$ respectively.

Microstructure and $\mathrm{X}$-ray studies of $\mathrm{Si}_{3} \mathrm{~N}_{4}-\mathrm{SiC}$ composites were made. It is seen from the optical micrograph (figure 3) that the large and small white grains are silicon carbide (A), surrounded by a felty and woolly mass, which is the assemblage of wool and whiskers of silicon nitride (B). The black patches are pores. The X-ray diffraction pattern is given in figure 4. It clearly indicates the peaks of $\mathrm{SiC}$ and $\mathrm{Si}_{3} \mathrm{~N}_{4}$. To probe into the reason for increase in the hot MOR values of the composite the fractured areas were microscopically examined after the test. The microstructure is shown in figure 5. The micrograph (figure 5) indicates bright grains which are silicon carbide (A), with an intergranular light grey phase of silicon nitride (B), and black areas which are pores. The same behaviour was observed for all other composites. The silicon carbide and silicon nitride phases were confirmed by using the Vickers microhardness indenter. In figure 5 the absence of the woolly intergranular (figure 3) phase of the starting material is noticed. Silicon nitride wool was converted into the consolidated phase at high temperatures and under load. It

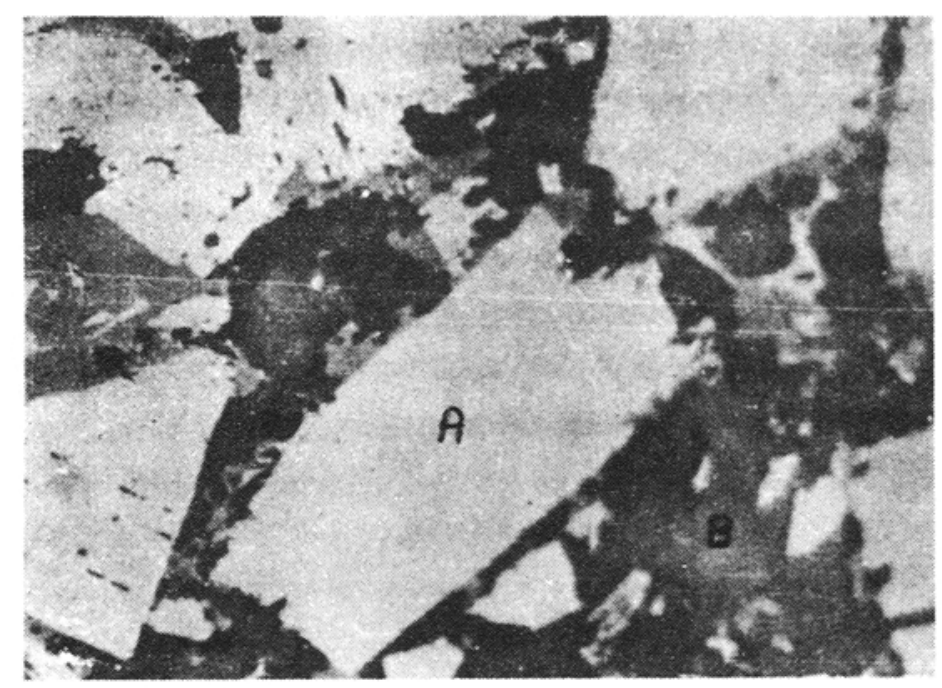

Figure 3. Optical micrograph of $\mathrm{Si}_{3} \mathrm{~N}_{4}-\mathrm{SiC}$ composite $\left(20 \% \mathrm{Si}_{3} \mathrm{~N}_{4}\right)$ after room temperature modulus of rupture.

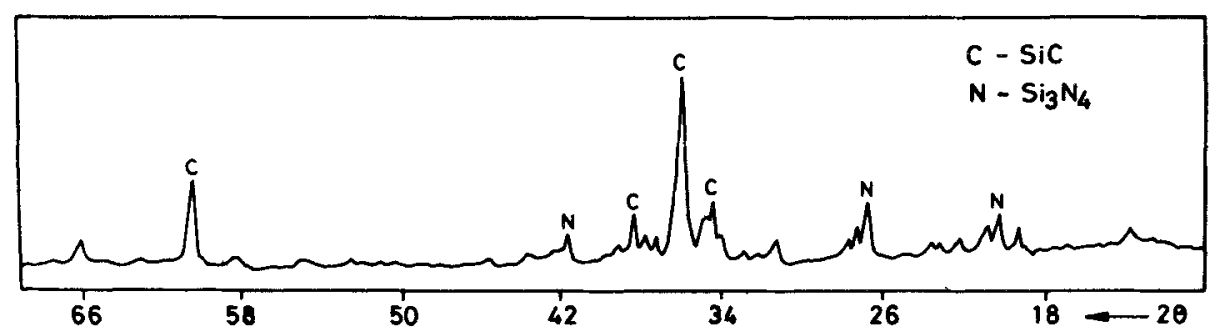

Figure 4. X-ray diffraction pattern of $\mathrm{Si}_{3} \mathrm{~N}_{4}-\mathrm{SiC}$ composite $\left(20 \% \mathrm{Si}_{3} \mathrm{~N}_{4}\right)$ 


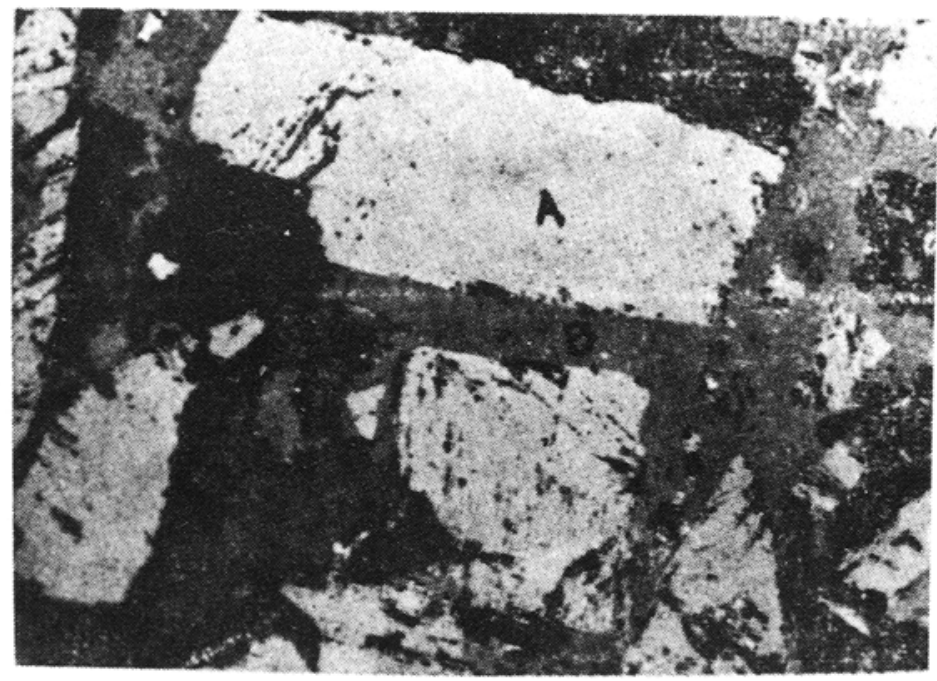

Figure 5. Optical micrograph of $\mathrm{Si}_{3} \mathrm{~N}_{4} \mathrm{SiC}$ composite $\left(20 \% \mathrm{Si}_{3} \mathrm{~N}_{4}\right)$ after hot modulus of rupture.

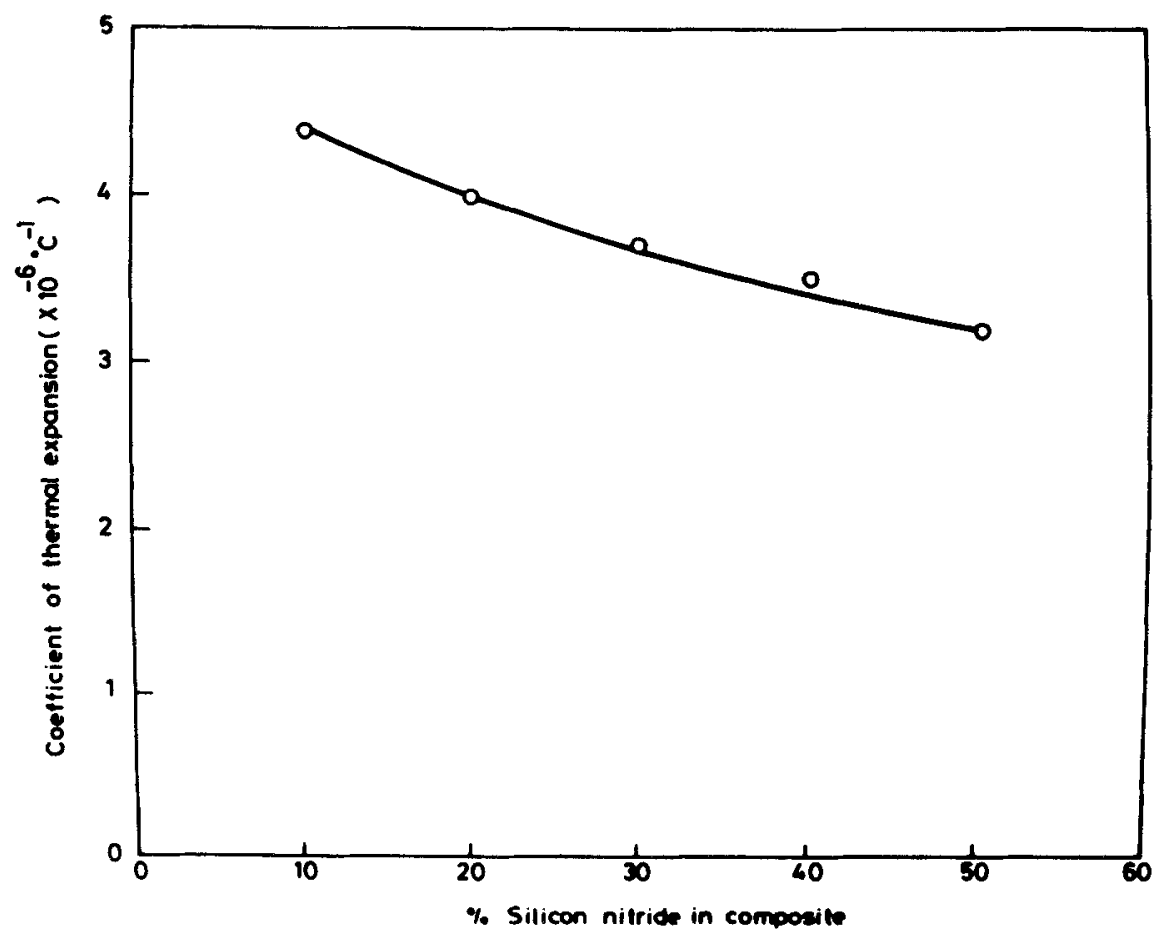

Figure 6. Coefficient of thermal expansion of $\mathrm{Si}_{3} \mathrm{~N}_{4}-\mathrm{SiC}$ composites.

may be noted that the increase in hot MOR values was due to the conversion of woolly $\mathrm{Si}_{3} \mathrm{~N}_{4}$ into a consolidated hard $\mathrm{Si}_{3} \mathrm{~N}_{4}$ intergranular phase. The increase of MOR with temperature is an important characteristic of the material. Hence these 
composites can be used for structural applications where strength and temperature are the most important parameters.

Figure 6 shows the thermal expansion coefficients of composites $(10,20,30,40$ and $50 \% \mathrm{Si}_{3} \mathrm{~N}_{4}$ ) in the temperature range $25-1000^{\circ} \mathrm{C}$. It is seen from the figure that the thermal expansion coefficient falls as the percentage of $\mathrm{Si}_{3} \mathrm{~N}_{4}$ in the composite increases. The thermal expansion coefficient of reaction-bonded silicon nitride is $2.4 \times 10^{-6}{ }^{\circ} \mathrm{C}^{-1}$ and that of aluminosilicate-bonded silicon carbide is $5.9 \times 10^{-6}{ }^{\circ} \mathrm{C}^{-1}$. Thermal expansion values of all the composites lie in between those of $\mathrm{Si}_{3} \mathrm{~N}_{4}$ and $\mathrm{SiC}$. Decrease of thermal expansion with increase in the percentage of silicon nitride in the composite is due to the lower thermal expansion of silicon nitride as compared to that of silicon carbide.

\section{References}

Buljan S T, Baldoni J G and Huckabee M L 1987 Am. Ceram. Sac. Bull. 66347

Govila R K, Mangels J A and Baer J R 1985 J. Am. Ceram. Soc. 68413

Jacobson N S and Smialek J L 1985 J. Am. Ceram. Soc. 68432

Krasotkina N I and Voronin N 1970 in Silicon carbide (ed.) I N Franstsevich (New York: Consultants Bureau) p. 71

Mecholsky J J 1989 Am. Ceram. Soc. Bull. 68367

Mukerji J and Reddy N K 1980 Indian Refract. Makers Assoc. J. 1310

North B and Kilchrist K E 1981 Am. Ceram. Soc. Bull. 60549

Pick A N 1979 Trans. J. Br. Ceram. Soc. 7813

Reddy N K and Mukerji J 1988 Indian Refract. Makers Assoc. J. 213

Tennery V J 1989 Am. Ceram. Soc. Bull. 68362

Trantina G G 1979 Nucl. Eng. Des. 5467

Uchida N, Koizumi M and Shimada M 1985 J. Am. Ceram. Soc. 68 C38

Washburn M E and Love R W 1962 Am. Ceram. Soc. Bull. 41447 